University of Nebraska - Lincoln

DigitalCommons@University of Nebraska - Lincoln

Agronomy \& Horticulture - Faculty Publications

Agronomy and Horticulture Department

$12-2-2005$

\title{
Establishment Stand Thresholds for Switchgrass Grown as a Bioenergy Crop
}

\author{
Marty R. Schmer \\ USDA-ARS, University of Nebraska-Lincoln, marty.schmer@ars.usda.gov \\ Kenneth P. Vogel \\ University of Nebraska-Lincoln, kvogel1@unl.edu \\ Robert B. Mitchell \\ University of Nebraska-Lincoln, rob.mitchell@ars.usda.gov \\ Lowell E. Moser \\ University of Nebraska-Lincoln, Imoser1@unl.edu \\ Kent M. Eskridge \\ University of Nebraska-Lincoln, keskridge1@unl.edu
}

See next page for additional authors

Follow this and additional works at: https://digitalcommons.unl.edu/agronomyfacpub

Part of the Plant Sciences Commons

Schmer, Marty R.; Vogel, Kenneth P.; Mitchell, Robert B.; Moser, Lowell E.; Eskridge, Kent M.; and Perrin, Richard K., "Establishment Stand Thresholds for Switchgrass Grown as a Bioenergy Crop" (2005).

Agronomy \& Horticulture -- Faculty Publications. 46.

https://digitalcommons.unl.edu/agronomyfacpub/46

This Article is brought to you for free and open access by the Agronomy and Horticulture Department at DigitalCommons@University of Nebraska - Lincoln. It has been accepted for inclusion in Agronomy \& Horticulture -Faculty Publications by an authorized administrator of DigitalCommons@University of Nebraska - Lincoln. 


\section{Authors}

Marty R. Schmer, Kenneth P. Vogel, Robert B. Mitchell, Lowell E. Moser, Kent M. Eskridge, and Richard K. Perrin 


\title{
Establishment Stand Thresholds for Switchgrass Grown as a Bioenergy Crop
}

\author{
M. R. Schmer, K. P. Vogel,* R. B. Mitchell, L. E. Moser, K. M. Eskridge, and R. K. Perrin
}

\begin{abstract}
Switchgrass (Panicum virgatum $\mathrm{L}$.) is a warm-season $\left(\mathrm{C}_{4}\right)$ perennial grass and a potential bioenergy crop. On-farm switchgrass field scale trials, which were initiated to obtain economic production information for switchgrass grown as a bioenergy crop in the northern Plains, provided information on establishment year stands and post-establishment year yields and stands both within and across fields and were used to determine if a stand threshold exists for switchgrass grown as a biomass energy crop. Switchgrass was seeded in 10 cropland fields, ranging in size from 3 to 9.5 ha, in Nebraska, South Dakota, and North Dakota in 2000 and 2001. The fields were selected to be representative of their region and eligible for the Conservation Reserve Program (CRP). Twelve sites within each field were geo-referenced, and switchgrass stand frequency was measured at each sample site. Biomass yields were estimated in late summer at the same withinfield sites using a clipped quadrat. Fields with low initial switchgrass stand frequencies showed a linear relationship between initial switchgrass stands and second year stands and biomass yields. Results from the 10 field, three-state study indicated that establishment year stand frequency level of $40 \%$ or greater, determined by a frequency grid, can be considered an establishment year stand threshold for establishment success and subsequent post-planting year biomass yields for switchgrass. An establishment year stand frequency of $25 \%$ would be adequate for a switchgrass conservation planting in which no harvests would be planned for several years.
\end{abstract}

$S_{t}$ WITCHGRASS is a warm-season perennial grass, native to the tallgrass prairie of North America, and is primarily used for summer forage, hay, and conservation plantings (Moser and Vogel, 1995). The United States Department of Energy designated switchgrass as a potential bioenergy feedstock because of its wide adaptability and high yields on marginal lands (Vogel, 1996). The land base for perennial biomass energy crops will likely be similar to the Conservation Reserve Program (CRP) (Walsh et al., 2003). Switchgrass use as a bioenergy feedstock, in addition to providing energy, might reduce net carbon gas emissions, improve soil and water quality, increase native wildlife habitat, and increase farm revenues (McLaughlin and Walsh, 1998; McLaughlin et al., 2002). Prior economic analysis has shown that the northern Great Plains have high potential for switchgrass bioenergy production (Walsh, 1998). Assuming a farm gate price of $\$ 44 / \mathrm{Mg}$, an estimated 2.1 to 7.2 million

M.R. Schmer, K.P. Vogel, and R.B. Mitchell, USDA-ARS, 344 Keim Hall, University of Nebraska, P.O. Box 830937, Lincoln, NE 685830937; K.M. Eskridge, Dep. of Statistics, 103 Miller Hall, L.E. Moser, Dep. of Agronomy and Horticulture, 272 Keim Hall, R.K. Perrin, Agricultural Economics Dep. 314A Filley Hall, University of Nebraska, Lincoln, NE 56583. Received 30 Mar. 2005. *Corresponding author (kpv@unlserve.unl.edu).

Published in Crop Sci. 46:157-161 (2006).

Forage \& Grazinglands

doi:10.2135/cropsci2005.0264

(c) Crop Science Society of America

677 S. Segoe Rd., Madison, WI 53711 USA hectares could potentially be allocated to switchgrass production in the northern Plains states of Nebraska, South Dakota, and North Dakota (McLaughlin et al., 2002). On-farm switchgrass field scale trials were initiated to obtain economic production information for switchgrass grown as a bioenergy crop in the northern Plains. The on-farm trials provided an opportunity to determine the relationships between establishment year stand and post-establishment year stand and yield both within and across fields in a large geographical area. Farmers producing switchgrass as a bioenergy feedstock need to know the minimum establishment year stand necessary on a field basis to produce economically viable biomass yields in post-establishment years.

Previous survey research in conservation plantings of warm-season prairie grass mixtures indicated that an established stand of 20 plants per $\mathrm{m}^{2}$ was similar to that of the tallgrass prairie and that a stand of 10 plants per $\mathrm{m}^{2}$ or greater can be classified as a good stand (Cornelius, 1944; Great Plains Agricultural Council, 1966). Launchbaugh and Owensby (1970) reported that mixed species stand densities of 10 plants per $\mathrm{m}^{2}$ or greater were adequate for grazing the year following establishment for switchgrass and other native, tallgrass species. Information is lacking on stand requirements for switchgrass grown specifically as a bioenergy feedstock.

Stand frequency measurements have been used to quantify seeding establishment, monitor species composition, evaluate herbicide efficacy, and to assess rangeland improvements (Hyder and Sneva, 1954; GreigSmith, 1983; Bonham, 1989; Vogel and Masters, 2001). Frequency is determined by the number of times in which a species occurs within a given repeated sample area and is expressed as a percentage of the total (GreigSmith, 1983). Hyder and Sneva (1954) found a high correlation coefficient between stand frequency and biomass for crested wheatgrass [Agropyron cristatum (L.) Gaertn.]. Smartt et al. (1974) reported a weak correlation between frequency and biomass on a heath vegetation area of England.

Vogel and Masters (2001) developed a 0.75- $\times 0.75-\mathrm{m}$ frequency grid subdivided into $25(15-\times 15-\mathrm{cm})$ cells that is useful in assessing plant populations at numerous sampling areas within a field and provides a conservative estimate of stand density. They reported a stand frequency of $50 \%$ or greater indicated a successful stand, a stand frequency of 50 to $25 \%$ indicated marginal to adequate stands, and a stand frequency less than $25 \%$ indicated a partial stand or unsuccessful establishment of warm-season grasses. Small plot research on switchgrass and big bluestem (Andropogon gerardii Vitman) showed biomass yield was not affected by stands when stand frequencies the year after establishment were $40 \%$

Abbreviations: CRP, Conservation Reserve Program; GPS, global positioning system; PLS, pure live seed. 


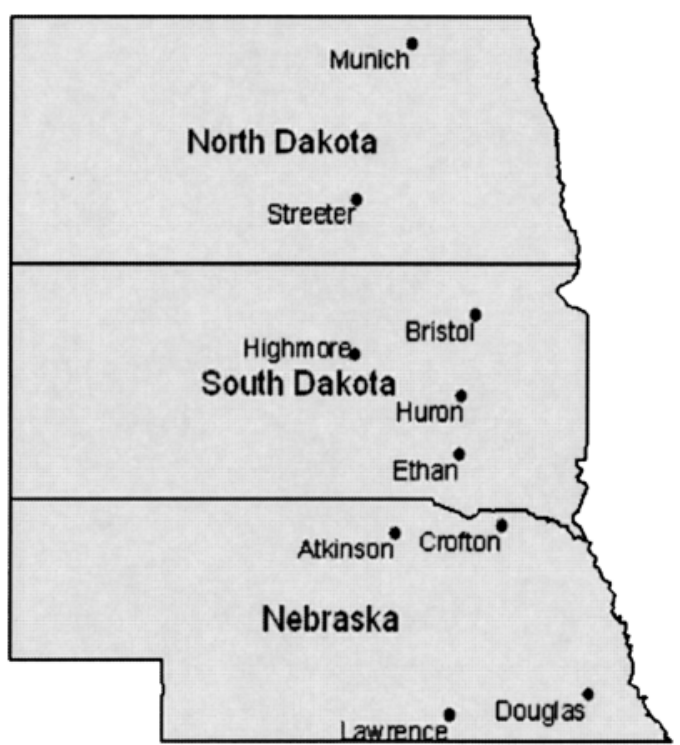

Fig. 1. Location of switchgrass fields in the northern Plains field_scale biomass production study.

or greater (Vogel, 1987; Masters, 1997). This suggests that a stand frequency threshold exists in the Central Plains for switchgrass and big bluestem. Once establishment stands reach a certain stand frequency threshold, a yield response from additional increases in stand frequency is negligible. In statistical terms, a threshold level for stand frequency is the value at which increases in the independent variable (establishment year stand frequency) do not result in an increase in the dependent variable (second year stand frequency and biomass yield).

The objectives of this study were to determine the relationship between establishment year and second year stands of switchgrass within fields; determine the relationship between establishment year stands and second year yields within fields; and determine if a stand threshold exists for switchgrass grown as a commercial biomass energy crop.

\section{MATERIALS AND METHODS}

The on-farm study was conducted on 10 fields in the northern Great Plains states of Nebraska, South Dakota, and North Dakota (Fig. 1). The fields selected had characteristics that would have qualified them for the CRP and were typical of their surrounding geographical region. Field size, field soil types, previous crop history, and switchgrass cultivars used are summarized in Table 1 . The fields are identified by the name of the nearest town. The Nebraska fields were established in 2000 except for the Atkinson field, which was established in 2001. The South Dakota and North Dakota fields were established in 2001.

Farm cooperators managed all aspects of crop production and harvest except that the Nebraska switchgrass fields were planted by USDA-ARS Lincoln Forage and Biomass Project personnel. A general set of recommended management practices based on previous small plot research were given to all farm cooperators. These management practices detailed seedbed preparation, planting depth, planting dates, herbicide use, and harvesting dates. Cultivars selected for each field were based on prior research within respective geographical regions. Seeding rates were 322 pure live seed (PLS) $\mathrm{m}^{-2}$. Soil samples were taken on each field before switchgrass establishment to assess soil fertility. No fertilizer was applied the establishment year. Second year fertilization recommendations varied with the potential productivity, establishment year weed populations, and previous climatic conditions of a field. Second year fertilization rates ranged from 67 to $112 \mathrm{~kg} \mathrm{~N} \mathrm{ha}^{-1}$, except that the Highmore, SD, field was not fertilized in the second year because of drought conditions.

The climatic conditions for the northern Plains generally consisted of below normal precipitation during the summers of 2000 to 2002 (Table 2). Abnormally dry conditions predominated throughout most of central and eastern Nebraska in 2000. Precipitation was near normal or above average for most of Nebraska, South Dakota, and North Dakota in 2001. By 2002, abnormally dry conditions occurred throughout most of Nebraska and central South Dakota (National Drought Mitigation Center, 2004). These conditions affected seedling establishment and negatively affected biomass production at most locations.

Switchgrass stand frequencies were made using a $0.75-\times$ $0.75-\mathrm{m}$ frequency grid in early summer (Vogel and Masters, 2001). For each sample site, the presence or absence of plants in each of the 25-grid cells was recorded. The grid was then flipped end-to-end until a total of 100 cells were observed for presence or absence of plants. The percentage of switchgrass tillers was recorded for each of 12 randomly selected sample sites within a given field. A 12-channel GPS receiver (Lowrance Globalmap 100'; Catoosa, OK) was used to geo-reference each sampled site for each field. The sample sites were used to obtain subsequent stand estimates and clipped quadrat yields the establishment and post-establishment year.

Biomass yields were estimated at each of the 12 plant frequency sample sites within a field using a $1-\times 1-\mathrm{m}$ quadrat in 2000 and a $0.3-\times 3.66-\mathrm{m}$ frame $\left(1.1 \mathrm{~m}^{2}\right)$ in 2001 and 2002 at the plant maturity stage of R3 to R5 (Moore et al., 1991) (panicle fully emerged from boot to postanthesis) or after a killing frost. Total plant biomass within the frame was clipped to a $10-\mathrm{cm}$ stubble height and weighed with a portable electronic scale (Intercomp CS750, Minneapolis, MN). A subsample was taken to determine dry matter and estimate biomass yields.

Regression analysis was used to determine the effect of establishment year stand on second year stand and quadrat yield within fields. Stand frequencies and quadrat yields were used in these analyses. Within-field data were analyzed by the GLM procedure in SAS (SAS Inst., 1999).

To test if a threshold level exists for switchgrass stands managed for biomass production at the field level, three threshold class criteria of 25,40 , and $50 \%$ were used. The basis for threshold class criteria was the classification system of Vogel and Masters (2001) and prior research on stand frequency and post-establishment yield of switchgrass grown in small plots (Vogel, 1987; Masters, 1997). For each threshold criterion, fields were placed into one of two classes which were (i) less than or equal to the threshold frequency level or (ii) greater than the threshold frequency level. For each class within each threshold criterion, the mean within-field regression coefficient was determined for the effect of establishment year switchgrass stand frequency on second year switchgrass stand frequency and biomass yield. Mean regression coefficients for each class within a threshold criterion were compared by a one-tailed, two-sample $t$ test (Dowdy and Wearden, 1991). The two-sample $t$ test determined if the mean

${ }^{1}$ Mention of a trade name does not constitute a guarantee of the product by USDA or the Univ. of Nebraska and does not imply its approval to the exclusion of other suitable products. 
Table 1. Field size, major soil type, previous crop, and switchgrass cultivar in the northern Plains field-scale switchgrass biomass production study.

\begin{tabular}{|c|c|c|c|c|}
\hline Location & $\begin{array}{l}\text { Field } \\
\text { size }\end{array}$ & Major soil type(s) & Previous crop(s) & Cultivar(s) $\dagger$ \\
\hline Lawrence, NE & ha & $\begin{array}{l}\text { Hastings (Fine, smectitic, mesic Udic Argiustolls) } \\
\text { Hall (Fine-silty, mixed, mesic Pachic Argiustolls) }\end{array}$ & sorghum + , maize $\S$ & CIR, TB, SH \\
\hline Douglas, NE & 9.5 & $\begin{array}{l}\text { Pawnee (Fine, smectitic, mesic Oxyaquic Vertic Argiudolls) } \\
\text { Wymore (Fine, smectitic, mesic Aquertic Argiudolls) }\end{array}$ & soybeanII & CIR, TB \\
\hline Atkinson, NE & 3.0 & $\begin{array}{l}\text { Valentine (Mixed, mesic Typic Ustipsamments) } \\
\text { Pivot (Sandy, mixed, mesic Entic Haplustolls) } \\
\text { Dunday (Sandy, mixed, mesic Entic Haplustolls) }\end{array}$ & pearl millet\# & TB \\
\hline Crofton, NE & 8.1 & $\begin{array}{l}\text { Crofton (Fine-silty, mixed, mesic Udic Ustorthents) } \\
\text { Nora (Fine-silty, mixed, mesic Udic Haplustolls) }\end{array}$ & common oat $\dagger \dagger$ & TB, SH \\
\hline Ethan, SD & 6.1 & $\begin{array}{l}\text { Houdek (Fine-loamy, mixed, mesic Typic Argiustolls) } \\
\text { Prosper (Fine-loamy, mixed, mesic Pachic Argiustolls) }\end{array}$ & maize & SH \\
\hline Huron, SD & 6.1 & $\begin{array}{l}\text { Dudley (Fine, smectitic, mesic Typic Natrustolls) } \\
\text { Tetonka (Fine, smectitic, mesic Ärgiaquic Argialbolls) }\end{array}$ & soybean & TB \\
\hline Highmore, SD & 6.1 & $\begin{array}{l}\text { Glenham (Fine-loamy, mixed, mesic Typic Argiustolls) } \\
\text { Prosper (Fine-loamy, mixed, mesic Pachic Argiustolls) }\end{array}$ & soybean & TB \\
\hline Bristol, SD & 6.1 & $\begin{array}{l}\text { Forman (Fine-loamy, mixed, frigid Calcic Argiudolls) } \\
\text { Buse (Fine-loamy, mixed, frigid Typic Calciudolls) } \\
\text { Aastad (Fine-loamy, mixed, frigid Pachic Hapludolls) }\end{array}$ & soybean & TB \\
\hline Streeter, ND & 8.1 & $\begin{array}{l}\text { Barnes (Fine-loamy, mixed, frigid Calcic Hapludolls) } \\
\text { Svea (Fine-loamy, mixed, frigid Pachic Hapludolls) }\end{array}$ & common oat & SB \\
\hline Munich, ND & 6.1 & $\begin{array}{l}\text { Hamerly (Fine-loamy, mixed, frigid Aeric Calciaquolls) } \\
\text { Tonka (Fine, smectitic, frigid Argiaquic Argialbolls) }\end{array}$ & soybean & SB \\
\hline
\end{tabular}

$\dagger$ CIR-Cave-in-Rock, TB-Trailblazer, SH-Shawnee, SB-Sunburst.

† Sorghum bicolor (L.) Moench.

$\S$ Zea mays L.

II Glycine max (L.) Merr.

\# Pennisetum glaucum (L.) R. Br.

$\dagger \dagger$ Avena sativa L.

Table 2. Mean growing season (April-October) precipitation and temperature at locations of switchgrass fields in the Northern Plains fieldscale switchgrass biomass production study. $\dagger$

\begin{tabular}{|c|c|c|c|c|c|c|c|c|c|c|}
\hline & Lawrence & Douglas & Atkinson & Crofton & Ethan & Huron & Highmore & Bristol & Streeter & Munich \\
\hline & $\mathbf{N E}$ & NE & $\mathbf{N E}$ & $\mathbf{N E}$ & SD & SD & SD & SD & ND & ND \\
\hline & \multicolumn{10}{|c|}{ Precipitation (mm) } \\
\hline 2000 & 490 & 525 & - & 477 & - & - & - & - & - & - \\
\hline 2001 & 619 & 773 & 668 & 636 & 438 & 506 & 371 & 382 & 365 & 427 \\
\hline 2002 & - & - & 322 & - & 465 & 297 & 260 & 414 & 379 & 480 \\
\hline \multirow[t]{2}{*}{ 30-yr mean } & 557 & 625 & 485 & 483 & 455 & 410 & 363 & 422 & 362 & 382 \\
\hline & \multicolumn{10}{|c|}{ Temperature $\left({ }^{\circ} \mathrm{C}\right)$} \\
\hline 2000 & 21.0 & 19.3 & - & 17.5 & - & - & - & - & - & - \\
\hline 2001 & 20.3 & 18.8 & 18.0 & 17.3 & 17.0 & 16.8 & 16.9 & 15.9 & 13.9 & 12.3 \\
\hline 2002 & - & - & 17.8 & - & 16.6 & 16.2 & 16.0 & 15.4 & 12.6 & 11.6 \\
\hline 30-yr mean & 19.2 & 18.3 & 17.1 & 17.8 & 16.9 & 16.1 & 16.4 & 15.3 & 14.6 & 13.2 \\
\hline
\end{tabular}

† Source: http://nndc.noaa.gov/(verified 1 September 2005).

regression coefficients of the two classes of a threshold criterion level differed significantly from each other. Significant differences indicate that the relationship of the independent (establishment year stand frequency) and dependent variable (second year stand frequency and biomass yield) changed significantly at the threshold classification level.

\section{RESULTS AND DISCUSSION}

Some farmer cooperators deviated from the recommendations to match their specific farming practices and equipment. Differing management practices and environmental conditions caused variation in establishment year switchgrass stand frequencies across locations (Table 3). For example, no herbicides were applied the establishment year at Ethan, SD, resulting in high weed stands (data not shown) and a low initial switchgrass stand. The Munich, ND, farm cooperator lacked a grassland drill, but instead broadcasted the switchgrass seed and incorporated it into the soil by shallow tillage. This resulted in inferior seedling development conditions and contributed to the low initial switchgrass stand.

\section{Within Fields}

Fields with low establishment year switchgrass stand frequencies tended to have a linear relationship with second year switchgrass stand frequencies. Conversely, fields with moderate to high establishment year switchgrass stand frequencies showed no relationship with second year switchgrass stand frequencies (Table 3). Only the Ethan, SD, field and the Munich, ND, field had a significant, linear relationship between establishment year switchgrass stand frequency and second year switchgrass stand frequency (Table 3 ).

A similar result was found for establishment year switchgrass stand frequencies and second year biomass yield (Table 4). Fields with low establishment year switchgrass stand frequencies showed a linear relationship with 
Table 3. Regression of second year stand frequency on establishment year stand frequency for individual switchgrass fields in the northern Plains field-scale biomass production study.

\begin{tabular}{|c|c|c|c|c|c|c|c|c|c|c|}
\hline \multirow[b]{3}{*}{ Location } & \multirow[b]{3}{*}{$\boldsymbol{N}$} & \multicolumn{4}{|c|}{ Stand frequency } & \multirow[b]{3}{*}{ Intercept } & \multirow[b]{3}{*}{$b \dagger$} & \multirow[b]{3}{*}{$\mathrm{SE}_{\mathrm{b}}+$} & \multirow[b]{3}{*}{$t$ value } & \multirow[b]{3}{*}{$r^{2} \S$} \\
\hline & & \multicolumn{2}{|c|}{ Year 1} & \multicolumn{2}{|c|}{ Year 2} & & & & & \\
\hline & & Mean & Range & Mean & Range & & & & & \\
\hline Lawrence, NE & 10 & 39 & $18-64$ & 55 & 24-93 & 22.55 & 0.86 & 0.5 & 1.73 & 0.27 \\
\hline Douglas, NE & 12 & 48 & $30-64$ & 34 & $6-60$ & 16.12 & 0.37 & 0.4 & 1.02 & 0.09 \\
\hline Atkinson, NE & 6 & 42 & 4-90 & 73 & 38-97 & 48.85 & 0.28 & 0.3 & 0.90 & 0.17 \\
\hline Crofton, NE & 12 & 50 & 27-78 & 45 & 27-91 & 46.36 & -0.06 & 0.3 & -0.2 & 0.01 \\
\hline Ethan, SD & 12 & 23 & $2-49$ & 61 & 17-95 & 36.41 & 1.04 & 0.3 & 3.32** & 0.52 \\
\hline Huron, SD & 12 & 92 & 73-99 & 80 & 50-95 & 127.53 & -0.5 & 0.5 & -0.95 & 0.08 \\
\hline Highmore, SD & 12 & 61 & 43-84 & 51 & 21-80 & 46.18 & 0.09 & 0.4 & 0.22 & $\mathbf{0 . 0 1}$ \\
\hline Bristol, SD & 12 & 45 & 39-58 & 59 & 47-74 & 62.39 & $-\mathbf{0 . 0 2}$ & 0.5 & $-\mathbf{0 . 0 3}$ & 0.01 \\
\hline Streeter, ND & 12 & 22 & $3-58$ & 41 & 13-70 & 27.58 & 0.47 & 0.3 & 1.45 & 0.17 \\
\hline Munich, ND & 12 & 13 & $0-47$ & 30 & 3-62 & 14.32 & 1.08 & 0.3 & 3.64** & 0.57 \\
\hline
\end{tabular}

* Significant at the 0.05 probability level.

$* *$ Significant at the $\mathbf{0 . 0 1}$ probability level.

$\dagger$ Linear regression coefficient.

$\ddagger$ Standard error of linear regression coefficient.

$\$$ Coefficient of determination.

Table 4. Regression of second year switchgrass biomass quadrat yield on establishment year stand frequency on sample sites for fields in the northern Plains field-scale biomass production study.

\begin{tabular}{|c|c|c|c|c|c|c|c|c|c|c|}
\hline \multirow[b]{2}{*}{ Location } & \multirow[b]{2}{*}{$N$} & \multicolumn{2}{|c|}{ Initial Stand } & \multicolumn{2}{|c|}{ Yield } & \multirow[b]{2}{*}{ Intercept } & \multirow[b]{2}{*}{$\boldsymbol{b} \dagger$} & \multirow[b]{2}{*}{$\mathrm{SE}_{\mathbf{b}}+$} & \multirow[b]{2}{*}{$t$ value } & \multirow[b]{2}{*}{$r^{2} \S$} \\
\hline & & Mean & Range & Mean & Range & & & & & \\
\hline & & \multicolumn{2}{|c|}{$\%$} & \multicolumn{2}{|c|}{$\mathrm{Mg} \mathrm{ha}^{-1}$} & & & & & \\
\hline Lawrence, NE & 14 & 39 & $18-64$ & 4.38 & $1.6-8.4$ & 1.93 & 0.063 & 0.04 & 1.62 & 0.18 \\
\hline Douglas, NE & 12 & 48 & $30-64$ & 7.28 & $2.5-14.4$ & 6.00 & 0.027 & 0.09 & 0.29 & 0.01 \\
\hline Atkinson, NE & 6 & 42 & 4-90 & 1.56 & $0.5-3.0$ & 0.28 & 0.026 & 0.01 & 4.18* & 0.81 \\
\hline Crofton, NE & 12 & $\mathbf{5 0}$ & $27-78$ & 4.78 & $3.2-7.4$ & 4.18 & 0.012 & 0.02 & 0.58 & 0.03 \\
\hline Ethan, SD & 12 & 23 & 2-49 & 2.60 & $0.6-4.9$ & 1.25 & 0.058 & 0.01 & $4.07 * *$ & 0.62 \\
\hline Huron, SD & 12 & 92 & 73-99 & 4.84 & 3.1-7.4 & 0.77 & 0.044 & 0.07 & 0.66 & 0.04 \\
\hline Highmore, SD & 12 & 61 & 43-84 & 1.13 & $0.1-2.7$ & 0.65 & 0.009 & 0.01 & 0.64 & 0.04 \\
\hline Bristol, SD & 12 & 45 & 39-58 & 7.19 & $5.5-10.1$ & 4.62 & 0.061 & 0.06 & 0.73 & 0.05 \\
\hline Streeter, ND & 12 & 22 & 3-58 & 4.64 & 3.1-7.4 & 3.56 & 0.039 & 0.02 & $2.15 *$ & 0.32 \\
\hline Munich, ND & 11 & $\mathbf{1 3}$ & 0-47 & 4.24 & $1.5-7.9$ & 3.00 & 0.103 & 0.03 & $4.05 * *$ & 0.65 \\
\hline
\end{tabular}

* Significant at the 0.05 probability level.

** Significant at the 0.01 probability level.

$\dagger$ Linear regression coefficient.

$\downarrow$ Standard error of linear regression coefficient.

$\$$ Coefficient of determination.

second year biomass yield, whereas locations with moderate to high establishment year switchgrass stand frequencies showed no relationship with second year biomass yield. The Atkinson, NE, Ethan, SD, Streeter, ND, and Munich, ND, fields all had a positive relationship with establishment year stand frequency and second year biomass yield (Table 4). Sample sites in fields with low initial stand frequencies tended to have lower biomass yields in the second year than sample sites with moderate to high initial stand frequencies. Fields with low mean stand frequencies also had large ranges in stands across fields. Fields that had moderate to high initial stand frequencies and with little within-field variability showed no response between establishment year stand frequency and second year biomass yield (Table 4).

\section{Threshold Levels}

Mean regression coefficients of second year switchgrass stand frequency on establishment year switchgrass stand frequency differed significantly at $P \leq 0.05$ between classes at each of the three threshold classification levels (Table 5). Mean regression coefficients of second year switchgrass stand frequency and establishment year switchgrass stand frequency were 0.863 for fields with an initial mean switchgrass stand frequency less than $25 \%$ and 0.146 for fields with an initial mean switchgrass stand frequency of $25 \%$ or greater (Table 5). The mean regression coefficients differed significantly between classes at the $25 \%$ threshold level. Mean regression coefficients of second year switchgrass stand frequency on establishment year switchgrass stand frequency differed significantly at $P \leq 0.01$ between classes at the $40 \%$ threshold level (Table 5). Mean regression coefficients for establishment year switchgrass stand frequency and second year switchgrass stand frequency differed significantly between classes at the $50 \%$ threshold level (Table $5)$. The $t$ value for the test of $b_{1} \geq b_{2}$ was greater for the $40 \%$ threshold than for the 25 and $50 \%$ threshold levels indicating that this threshold level is a better indicator of minimally successful stands for switchgrass biomass production than the other tested levels.

Mean regression coefficients of second year biomass yield on establishment year switchgrass stand frequency did not differ between classes at the $25 \%$ threshold level 
Table 5. Comparison of mean regression coefficients between stand frequency classes to determine if relationships between initial switchgrass stand frequency and second year stand and yield differed according to initial stand threshold levels across fields in the northern Plains field-scale biomass production study.

\begin{tabular}{|c|c|c|c|}
\hline $\begin{array}{l}\text { Initial stand } \\
\text { frequency }\end{array}$ & $\begin{array}{l}\text { Study } \\
\text { sites }\end{array}$ & $\boldsymbol{b} \dagger$ & $t$ value \\
\hline & \multicolumn{2}{|c|}{ _ Stand frequency } & \\
\hline$<\mathbf{2 5} \%$ & 3 & 0.863 & $2.58 *$ \\
\hline$>\mathbf{2 5} \%$ & 7 & 0.146 & \\
\hline$<\mathbf{4 0} \%$ & 4 & 0.863 & $4.36 * *$ \\
\hline$>40 \%$ & 6 & 0.027 & \\
\hline$<\mathbf{5 0} \%$ & 7 & 0.583 & $2.73 *$ \\
\hline \multirow[t]{2}{*}{$>\mathbf{5 0} \%$} & 3 & $-\mathbf{0 . 1 5 7}$ & \\
\hline & \multicolumn{2}{|c|}{ - Biomass yield } & \\
\hline$<\mathbf{2 5} \%$ & 3 & $6.67 \times 10^{-2}$ & 1.85 \\
\hline$>\mathbf{2 5} \%$ & 7 & $3.46 \times 10^{-2}$ & \\
\hline$<\mathbf{4 0} \%$ & 4 & $6.58 \times 10^{-2}$ & $2.45 *$ \\
\hline$>\mathbf{4 0} \%$ & 6 & $2.98 \times 10^{-2}$ & \\
\hline$<\mathbf{5 0} \%$ & 7 & $5.39 \times 10^{-2}$ & 1.86 \\
\hline$>\mathbf{5 0} \%$ & 3 & $2.17 \times 10^{-2}$ & \\
\hline
\end{tabular}

* Significant at the 0.05 probability level.

** Significant at the 0.01 probability level.

$\dagger$ Mean of linear regression coefficients.

(Table 5). Mean regression coefficients of second year biomass yield on establishment year switchgrass stand frequency differed significantly $(P \leq 0.05)$ between classes at the $40 \%$ threshold level (Table 5). The variation of second year biomass yields, across locations, was likely a result of environmental factors rather than initial switchgrass stands for fields with an initial mean switchgrass stand frequency of $40 \%$ or greater. Fields with an initial mean switchgrass stand frequency less than $50 \%$ had a greater mean regression coefficient with second year biomass yields than fields with an initial mean switchgrass stand frequency of $50 \%$ or greater (Table 5 ). However, the mean regression coefficients did not differ between classes at the $50 \%$ threshold level.

\section{SUMMARY}

At the field scale in the northern Great Plains, second year biomass yields are limited by establishment stands only if initial stands are less than $40 \%$. If establishment year switchgrass stands on a field have threshold frequency levels of $40 \%$ or more, post-establishment biomass yields and post-establishment switchgrass stands are likely influenced more by site and environmental variation than by initial stand frequency. Failure to obtain a fully successful switchgrass stand the establishment year (stand frequency of $40 \%$ or greater) can limit biomass yield in post-establishment years resulting in decreased revenue. Initial stand frequencies of $40 \%$ or greater, as determined by a frequency grid, can be considered an establishment year stand threshold for switchgrass grown as a bioenergy crop in the northern Great Plains, USA. Establishment year switchgrass stand frequencies of $25 \%$ or greater should be considered successful if the field is managed for conservation purposes given that biomass or forage will not be harvested for several years following planting.

\section{REFERENCES}

Bonham, C.D. 1989. Measurements of terrestrial vegetation. Wiley Interscience, New York.

Cornelius, D.R. 1944. Revegetation in the tall grass prairie region. J. Am. Soc. Agron. 36:393-400.

Dowdy, S., and S. Wearden. 1991. Statistics for research. John Wiley \& Sons, New York.

Great Plains Agricultural Council. 1966. A stand establishment survey of grass plantings in the Great Plains. Rep. 23. Nebraska Agric. Exp. Stn. Great Plains Counc. Univ. of Nebraska, Lincoln.

Greig-Smith, P. 1983. Quantitative plant ecology. Blackwell Scientific Publ., London.

Hyder, D.N., and F.A. Sneva. 1954. A method for rating the success of range seeding. J. Range Manage. 7:89-90.

Launchbaugh, J.L., and C.E. Owensby. 1970. Seeding rate and firstyear stand relationships for six native grasses. J. Range Manage. 23:414-417.

Masters, R.A. 1997. Influence of seeding rate on big bluestem establishment with herbicides. Agron. J. 89:947-951.

McLaughlin, S.B., D.G. De La Torre Ugarte Jr, C.T. Garten, L.R. Lynd, M.A. Sanderson, V.R. Tolbert, and D.D. Wolf. 2002. Highvalue renewable energy from prairie grasses. Environ. Sci. Technol. 36:2122-2129.

McLaughlin, S.B., and M.E. Walsh. 1998. Evaluating environmental consequences of producing herbaceous crops for bioenergy. Biomass Bioenergy 14:317-324.

Moore, K.J., L.E. Moser, K.P. Vogel, S.S. Waller, B.E. Johnson, and J.F. Pedersen. 1991. Describing and quantifying growth stages of perennial forage grasses. Agron. J. 83:1073-1077.

Moser, L.E., and K.P. Vogel. 1995. Switchgrass, big bluestem, and indiangrass. p. 409-420. In R.F Barnes et al (ed.) Forages: An introduction to grassland agriculture. Iowa State Univ. Press, Ames, IA.

National Drought Mitigation Center. 2004. Archive [Online]. Available at www.drought.unl.edu/dm/archive.html; verified 12 September 2005.

SAS institute. 1999. The SAS online doc v. 8. SAS Inst., Cary, NC

Smartt, P.F., S.E. Meacock, and J.M. Lambert. 1974. Investigation into the properties of quantitative vegetational data: I. Pilot study. J. Ecol. 62:735-759.

Vogel, K.P. 1987. Seeding rates for establishing big bluestem and switchgrass with preemergence atrazine applications. Agron. J. 79: 509-512.

Vogel, K.P. 1996. Energy production from forages (or American agriculture-back to the future). J. Soil Water Conserv. 51:137-139.

Vogel, K.P., and R.A. Masters. 2001. Frequency grid-a simple tool for measuring grassland establishment. J. Range Manage. 54:653-655.

Walsh, M.E. 1998. U.S. bioenergy crop economic analyses: Status and needs. Biomass Bioenergy 14:341-350.

Walsh, M.E., D.G. De La Torre, H. Shapouri, and S.P. Slinsky. 2003. Bioenergy crop production in the United States. Environ. Resour. Econ. 24:313-333. 